\title{
DAMPAK SOSIAL DAN EKONOMI PENUTUPAN LOKALISASI TELEJU TERHADAP MARAKNYA PANTI PIJAT DAN IMPLIKASINYA TERHADAP KERESAHAN MASYARKAT DI KOTA PEKANBARU
}

\author{
Mulia Sosiady \\ Dosen Fakultas Ekonomi dan Ilmu Sosial \\ Universitas Islam Negeri Sulthan Syarif Kasim Riau \\ email: muliasosiady@uin-suska.ac.id \\ Ermansyah \\ Dosen Fakultas Ekonomi dan Ilmu Sosial \\ Universitas Islam Negeri Sulthan Syarif Kasim Riau \\ email:ermansyah@uin-suska.ac.id
}

\begin{abstract}
Abstrak
Penelitian ini berlokasi pada Panti Pijat yang tersebar pada Delapan Kecamatan di Kota Pekanbaru, penelitian ini berlangsung dari bulan Juli sampai selesai Penelitian ini dilatarbelakangi oleh maraknya Panti Pijat yang hadir Pasca Penutupan Lokalisasi Teleju yang di "Bersihkan "Pemerintah Kota Pekanbaru pada tahun 2009 di era Pemerintahan Bapak Drs.H Herman Abdullah, MM sebagai walikota. Penelitian ini bertujuan Bagaimana Dampak Penutupan Lokalisasi Teleju Terhadap Maraknya Panti Pijat di Kota Pekanbaru dan Bagaimana Implikasi Kehadiran Panti Pijat tersebut terhadap Keresahan Masyarakat di Kota Pekanbaru Data yang Penulis dapatkan di Lapangan terdapat 147 Panti Pihat yang tersebar di Kota Pekanbaru,baik Panti Pijat Tradisional maupun Panti Pijat Moderen yang terkenal dengan anama SPA dan Massage, Panti Pijat terbanyak ada di Kecamatan Marpoyan Damai dan Panti Pijat dengan Perkenbangan tercepat ada di Kecamatan Tenayan Raya,Kesimpulan pada penelitian ini, dimana Panti Pijat di Kota Pekanbaru tumbuh seperti jamur dimusim hujan, dan mayoritas Panti Pijat di Pekanbaru tidak memiliki Izin Resmi dari Pemerintah Kota Pekanbaru,dari 147 Panti Pijat hanya 11 Panti Pijat yang mengantongi izin Pemerintah Kota Pekanbaru, dan Kehadiran Panti Pijat di Kota Pekanbaru menimbulkan Keresahan di Masyarakat karena Banyak tindak kriminal yang terjadi seperti Pemuda yang sering berkumpul dan mabuk-makukan di sekitar panti Pijat serat menjadi tontonan anak-anak dibawah umur.
\end{abstract}

Kata Kunci : Teleju, Panti Pijat, Keresahan Masyarakat, Kota Pekanbaru.

\section{PENDAHULUAN}

Konsep Prostitusi dibangun pada era Ali Sadikin ketika menjadi Gubernur Jakarta, tempat Prostitusi itu antara lain Kramak Tunggak, yang akhirnya ditutup oleh Gubernur Sutiyoso, Kalijodo baru saja rata dengan tanah oleh Gubernur Jakarta Bapak Basuki Tjahya Purnama, Gang Dolly di Kota Surabaya akhirnya ditutup oleh Walikota Surabaya Ibu. Tri Risma Harini, Begitu juga di Pekanbaru yang dikenal dengan nama kawasan Prostitusi Teleju.
Lokalisasi Teleju Letaknya di Jalan Karya Bersama, Kelurahan Rejosari Kota Pekanbaru, hampir 35 tahun berdiri, sekitar 400 unit rumah yang ada di Lokalisasi, dihuni oleh 425 PSK, 197 Germo, 125 Orang anak sekolah yang berada di Lokasi Prostidan akhirnya pada tahun 2009 Lokalisasi Teleju resmi di "bersihkan" oleh Pemerintah Kota Pekanbaru dibawah Kepemimpinan Bapak Herman Abdullah.

Bekas wanita penghibur pindah ke kawasan Perumahan Jundul dengan membuka praktek panti pijat, sehingga 
kawasan Perumahan Jundul menjadi tempat semi prostitusi setelah Teleju di bersihkan, ada pula yang pindah ke kawasan Permata yang membuka usaha Pijat Tradisonal dan beberapa wilayah di Kota Pekanbaru

Menurut Badan Perizinan Kota Pekanbaru, Banyak diantara panti pijat yang tidak mempunyai izin atau ilegal, tapi tidak semua panti pijat yang tidak berizin, ada juga kesadaran dari pengelola Panti Pijat tersebut yang mendaftarkan usaha meskipun alasanya takut dirazia Satuan Pamong Praja (Satpol PP) Kota Pekabaru.

Tabel 1.1 Jumlah Panti Pijat di Pekanbaru

\begin{tabular}{|c|l|c|c|c|}
\hline No & $\begin{array}{c}\text { Wilayah/ } \\
\text { Kecamatan }\end{array}$ & Berizin & $\begin{array}{c}\text { Tidak } \\
\text { Berizin }\end{array}$ & Jumlah \\
\hline 1. & Marpoyan Damai & - & 37 & 37 \\
\hline 2. & Tampan & - & 8 & 8 \\
\hline 3. & Sukajadi & 7 & 9 & 16 \\
\hline 4. & Bukit Raya & & 22 & 22 \\
\hline 5. & Senapelan & 3 & 12 & 15 \\
\hline 6. & Sail & - & 7 & 7 \\
\hline 7. & Pekanbaru Kota & - & 13 & 13 \\
\hline 8. & Lima Puluh & 1 & 28 & 29 \\
\hline & Jlh. Panti Pijat & $\mathbf{1 1}$ & $\mathbf{1 3 6}$ & $\mathbf{1 4 7}$ \\
\hline
\end{tabular}

Sumber : BPTMP Kota Pekanbaru 2015

Dari data diatas pada Kecamatan Marpoyan Damai berdiri paling banyak Panti Pijat sebanyak 37 usaha, Jumlah Panti Pijat yang tidak memiliki izin sebanyak 136 usaha, dan Panti Pijat yang memiliki Izin sebanyak 11 usaha Panti Pijat, Panti Pijat yang tidak memiliki izin paling banyak di Kecamatan Sukajadi dengan jumlah 7 usaha Panti Pijat.

Tabel 1.2

Perkembangan Jumlah Panti Pijat di Kota Pekanbaru

\begin{tabular}{|c|c|c|c|}
\hline No & Tahun & $\begin{array}{c}\text { Jumlah } \\
\text { Panti Pijat }\end{array}$ & $\begin{array}{c}\text { Persentase } \\
\text { Perkembangan }\end{array}$ \\
\hline 1. & 2013 & 117 & - \\
\hline 2. & 2014 & 137 & $0,2 \%$ \\
\hline 3. & 2015 & 147 & $0,1 \%$ \\
\hline 4. & 2016 & 224 & $0,8 \%$ \\
\hline
\end{tabular}

Sumber : Dinas Sosial Kota Pekanbaru dan Pemakaman 2016
Dari data diatas Penulis tertarik mengangkat Judul Penelitian : "dampak sosial dan ekonomi penutupan lokalisasi teleju terhadap maraknya panti pijat dan Implikasinya Terhadap Keresahan Masyarkat di Kota Pekanbaru".

\subsection{Rumusan Masalah}

Adapun Rumusan masalah pada Penelitian ini adalah :

1. Bagaimana Dampak Penutupan Lokalisasi Teleju Berpengaruh terhadap Maraknya Panti Pijat di Kota Pekanbaru?

2. Bagaimana Dampak Maraknya Panti Pijat Berpengaruh terhadap Keresahan Masyarakat di Kota Pekanbaru?

\subsection{Tujuan Penelitian}

Adapun tujuan dari penelitian ini adalah sebagai berikut:

1. Untuk mengetahui Bagaimana Dampak Penutupan Lokalisasi Teleju Berpengaruh terhadap Maraknya Panti Pijat di Kota Pekanbaru?

2. Untuk mengetahui Bagaimana Dampak Maraknya Panti Pijat Berpengaruh terhadap Keresahan Masyarakat di Kota Pekanbaru

\subsection{Manfaat Penelitian}

1. Peneliti, sebagai bahan untuk pengembangan ilmu tentang Sosial Ekonomi Masyarakat Kota Pekanbaru sehingga Peneliti dapat mengetahui dengan pasti masalah-masalah yang terjadi dan dapat memberi rekomendasai kepada pihak-pihak yang terkait terhadap Kondisi Sosial Ekonomi yang terjadi.

2. Pemko Pekanbaru, sebagai bahan dalam mengambil kebijkan dalam pengelolaan tempat prostitusi, yang muncul dengan nama Panti Pijat dan tempat yang sejenisnya yang sangat marak akhir-akhir ini berkembang di Kota Pekanbaru.

3. Peneliti Selanjutnya, sebagai bahan referensi dalam melanjutkan kajiankajian terbaru tentang masalah Sosial Ekonomi terutama masalah kehadiran tempat-tempat semi Prostitusi seperti Panti Pijat dan sebagainya. 


\section{LANDASAN TEORI}

\subsection{Pengertian Penyimpangan Sosial}

Penyimpangan adalah segala bentuk perilaku yang tidak menyesuaikan diri dengan kehendak masyarakat. Dengan kata lain, penyimpangan adalah tindakan atau perilaku yang tidak sesuai dengan norma dan nilai yang dianut dalam lingkungan baik lingkungan keluarga maupun masyarakat. Penyimpangan terjadi apabila seseorang atau kelompok tidak mematuhi norma dan nilai yang berlaku dalam masyarakat. Penyimpangan terhadap nilai dan norma dalam masyarakat disebut dengan deviasi (deviation), sedangkan pelaku atau individu yang melakukan penyimpangan disebut divian (deviant).

Salah satu Penyimpangan Sosial adalah Pelacuran atau prostitusi. Pelacuran adalah penjualan jasa seksual, seperti seks oral atau hubungan seks, untuk uang.Seseorang yang menjual jasa seksual disebut pelacur, yang kini sering disebut dengan istilah pekerja seks komersial (PSK).

Prostitusi ditinjau dari sudut manapun merupakan suatu kegiatan yang berdampak negatif seperti :

1. Secara sosialogis prostitusi merupakan perbuatan amoral yang bertentangan dengan norma dan etika yang ada di dalam masyarakat.

2. Dari aspek kewanitaan, prostitusi merupakan kegiatan merendahkan martabat wanita.

3. Dari aspek kesehatan, praktek prostitusi merupakan media yang sangat efektif untuk menularnya penyakit kelamin dan kandungan yang sangat berbahaya. Sudah banyak upaya menghapus praktek prostitusi dari lingkungan pergaulan masyarakat. Namun kenyataannya prostitusi masih tetap ada

\subsection{Pengertian Prostitusi}

Prostitusi (pelacuran) berasal dari bahasa latin pro-stituere atau prostauree, yang berarti membiarkan diri berbuat zinah, malakukan persundalan, pergundikan. Sedang prostitue adalah pelacur, dikenal pula dengan istilah WTS atau Wanita Tuna Susila. Tuna susila atau tindak susila itu diartikan sebagai kurang beradab karena keroyalan relasi seksualnya, dalam bentuk penyerahan diri pada banyak laik-laki untuk pemuasan seksual, dan mendapatkan imbalan jasa atau uang bagi pelayanannya.

Menurut Soerjono Soekanto, pelacuran dapat diartikan sebagai suatu pekerjaan yang bersifat menyerahkan diri kepada umum untuk melakukan perbuatanperbuatan seksual dengan mendapat upah. Dari pengertian yang dibuatnya, tampak dengan jelas bahwa Soerjono Soekanto menggunakan prespektif motif dalam menjelaskan definisi pelacuran.

\subsection{Faktor Penyebab Prostitusi}

Menurut Suwarsono Muhammad tahun 2009 di Kawasan Sarkem Yogyakarta dengan metode wawancara terhadap 20 wanita yang terlibat prostitusi dapat disimpulkan bahwa faktor penyebab mereka terjun ke dunia 'hitam' tersebut adalah sebagai berikut :

1. Faktor ekonomi, yaitu sebanyak $45 \%$,

2. Faktor frustasi karena putus cinta, sebanyak $20 \%$

3. Faktor lingkungan $15 \%$

4. Faktor hasrat seks $10 \%$, dan

5. Faktor tipuan mucikari yang katanya hendak mencarikan kerja yang pantas dan gajinya besar, sebanyak $10 \%$

Upaya-upaya yang dilakukan Pemerintah dalam penanggulangan prostitusi antara lain dengan cara :

1. Melarang dengan undang-undang, diikuti oleh razia-razia/penangkapan

2. Dengan pencatatan dan pengawasan kesehatannya

3. Ditampung di tempat-tempat jauh di luar kota dengan pengawasan dan perawatan serta diberikan penerangan-penerangan agama atau pendidikan juga diadakan laranganlarangan terhadap anak-anak muda yang mengunjungi tempat tersebut

4. Rehabilitasi dalam asrama-asrama dimana para pelacur yang tertangkap diseleksi, yang dianggap masih dapat diperbaiki ditampung dalam asrama, 
mereka dididik dalam keterampilan, agama dan lain-lain dipersiapkan untuk dapat kembali ke masyarakat sebagai warga yang baik kembali.

\subsection{Dampak Prostitusi dan Upaya Penanggulangannya}

Suatu penyebab pasti menghasilkan akibat, begitu pula dengan faktor-faktor penyebab pelacuran.Akibat daripada pelacuran dapat terjadi pada diri si pelaku maupun masyarakat yang tinggal di sekitar tempat dimana masalah terjadi.

Akibat dari pelacuran bagi diri si pelaku (bukan hanya PSK saja tetapi juga si tamu) pada umumnya berupa akibat biologis atau akibat terhadap tubuh para pelaku. Akibat biologis terebut antara lain penyakit kelamin dan kulit terutama syphilis dan gonorrhoe (kencing nanah) yang disebabkan oleh penularan virus maupun bakteri saat berhubungan seksual sampai virus HIV yang menyebabkan AIDS atau pelemahan sistem imun tubuh, serta disfungsi seksual (tidak berfungsinya organ seksual) misalnya impotensi, anorgasme, nymfomania, satyriasis, dan ejakulasi premature.

Berbeda dengan akibat pelacuran bagi diri si pelaku sendiri yang memiliki dampak biologis, akibat pelacuran bagi masyarkat yang tinggal di sekitar masalah sosial tersebut cenderung bersifat sosiologis, yakni rusaknya rumah tangga, demoralisasi masyarakat hingga munculnya korelasi dengan kriminalitas dan narkotika.

Rusaknya rumah tangga terjadi akibat ketiadaan sikap setia antara seorang suami dan istri dalam menjalankan rumah tangga sekaligus membina keluarganya. Adanya kegiatan prostitusi seakan menggoda suami maupun istri untuk memenuhi atau memuaskan keinginan seksual mereka tanpa memperhatikan keberadaan pasangan mereka serta anakanak mereka.Rasa curiga dan saling tidak percaya pun muncul dalam rumah tangga yang telah dibina.
Prostitusi ditinjau dari sudut manapun merupakan suatu kegiatan yang berdampak tidak baik (negatif).

Dampak negatif tersebut antara lain :

1. Secara sosiologis, prostitusi merupakan perbuatan amoral yang bertentangan dengan norma dan etika yang ada di

2. dalam masyarakat,

3. Dari aspek pendidikan, prostitusi merupakan kegiatan yang demoralisasi.

4. Dari aspek kewanitaan, prostitusi merupakan kegiatan merendahkan martabat wanita

5. Dari aspek ekonomi, prostitusi dalam prakteknya sering terjadi pemerasan tenaga kerja.

6. Dari aspek kesehatan, praktek prostitusi merupakan media yang sangat efektif untuk menularnya penyakit kelamin dan kandungan yang sangat berbahaya

7. Dari aspek kamtibmas, praktek prostitusi dapat menimbulkan kegiatan-kegiatan criminal.

8. Dari aspek penataan kota, prostitusi dapat menurunkan kualitas dan estetika lingkungan perkotaan.

Sebenarnya pemerintah telah menempuh berbagai upaya untuk mengatasi masalah pelacuran dan akibat yang ditimbulkannya, diantaranya dengan sering mengadakan rasia oleh trantib untuk menangkap dan kemudian memberi pengarahan kepada para pelacur jalanan, namun cara itu tidak efektif menekan perkembangan prostitusi.

Upaya-upaya yang dilakukan Pemerintah dalam penanggulangan prostitusi antara lain dengan cara :

1. Melarang dengan undang-undang, diikuti oleh razia-razia/penangkapan.

2. Denganpencatatan dan pengawasan kesehatannya.

3. Ditampung di tempat-tempat jauh di luar kota dengan pengawasan dan perawatan serta diberikan penerangan-penerangan agama atau pendidikan juga diadakan larangan- 
larangan terhadap anak-anak muda yang mengunjungi tempat tersebut.

4. Rehabilitasi dalam asrama-asrama dimana para pelacur yang tertangkap diseleksi, yang dianggap masih dapat diperbaiki ditampung dalam asrama, mereka dididik dalam keterampilan, agama dan lain-lain dipersiapkan untuk dapat kembali ke masyarakat sebagai warga yang baik kembali.

\subsection{Zina Menurut Hukum Islam}

Pelacuran dalam Agama Islam juga disebut dengan zina, zina termasuk perbuatan dosa besar. Hal ini dapat dilihat dari urutan penyebutannya setelah dosa musyrik dan membunuh tanpa alasan yang haq(benar), Allah berfirman:

"Dan orang-orang yang tidak menyembah tuhan yang lain beserta Allah dan tidak membunuh jiwa yang diharamkan Allah kecuali dengan (alasan) yang benar dan tidak berzina." (QS. Al-Furqaan: 68). Islam melarang dengan tegas perbuatan zina karena perbuatan tersebut adalah kotor dan keji. Allah berfirman:

"Dan janganlah kamu mendekati perbuatan zina. Sesungguhnya zina itu suatu perbuatan yang keji dan suatu jalan yang buruk". (QS. Al-Isra': 32).

\subsection{Penelitian Terdahulu}

\begin{tabular}{|c|c|c|c|c|}
\hline No & Nama Peneliti & Judul Penelitian & Lokasi Penelitian & Kesimpulan \\
\hline 1. & $\begin{array}{l}\text { Astry Sandra } \\
\text { Amalia }\end{array}$ & $\begin{array}{l}\text { Dampak } \\
\text { Lokalisasi } \\
\text { Pekerja Seks } \\
\text { Komersial } \\
\text { (Psk) Terhadap } \\
\text { Masyarakat } \\
\text { Sekitar }\end{array}$ & $\begin{array}{l}\text { Desa } \\
\text { Purwajaya Kabupaten } \\
\text { Kutai Kartanegara }\end{array}$ & $\begin{array}{l}\text { Dari } \\
\text { hasil penelitian diperoleh } \\
\text { gambaran bahwa secara } \\
\text { keseluruhan memang } \\
\text { benar adanya dapak yang di } \\
\text { timbulkan dari adanya } \\
\text { lokalisasi komplek } \\
\text { pekerja seks komersial (PSK) } \\
\text { yaitu berupa penyebaran } \\
\text { penyakit, berdampak } \\
\text { terhadap perkembangan sosial } \\
\text { dan ekonomi masyarakat, juga } \\
\text { terjadi reaksi di masyarakat. } \\
\text { Dan hasil penelitian ini di } \\
\text { harapkan dapat member } \\
\text { kontribusi kepada pemerintah } \\
\text { dan PEMDA dalam membuat } \\
\text { strategi keni katam } \\
\text { kebijakan dalam penataan } \\
\text { wilayah Kabupaten Kutai } \\
\text { Kartanegara } \\
\text { khususnya Desa Purwajaya. }\end{array}$ \\
\hline 2. & $\begin{array}{l}\text { Hartini } \\
\text { Retnaningsih }\end{array}$ & $\begin{array}{l}\text { Dampak Sosial } \\
\text { Penutupan } \\
\text { Lokalisasi } \\
\text { Dolly }\end{array}$ & Surabaya & $\begin{array}{l}\text { Penutupan lokalisasi Dolly } \\
\text { merupakan dilema. Di satu sisi } \\
\text { pelacuran } \\
\text { bertentangan dengan ajaran } \\
\text { agama dan bahkan dapat } \\
\text { berdampak buruk terhadap } \\
\text { perkembangan jiwa anak-anak } \\
\text { di sekitarnya, sedangkan di sisi } \\
\text { lain terdapat masalah } \\
\text { ekonomi yang perlu turut } \\
\text { dicarikan solusi terbaiknya. }\end{array}$ \\
\hline 3. & $\begin{array}{l}\text { Janif Zulfiqa, } \\
\text { Nur Fitriah, } \\
\text { Enos Paselle }\end{array}$ & \begin{tabular}{|l|} 
Analsis \\
Kebijakan \\
Penutupan \\
\end{tabular} & $\begin{array}{l}\text { Balikpapan Kalimantan } \\
\text { Timur }\end{array}$ & $\begin{array}{l}\text { Dalam penanganan dampak } \\
\text { sosial penutupan lokalisasi KM } \\
17 \text { Balikpapan perlu kajian }\end{array}$ \\
\hline
\end{tabular}




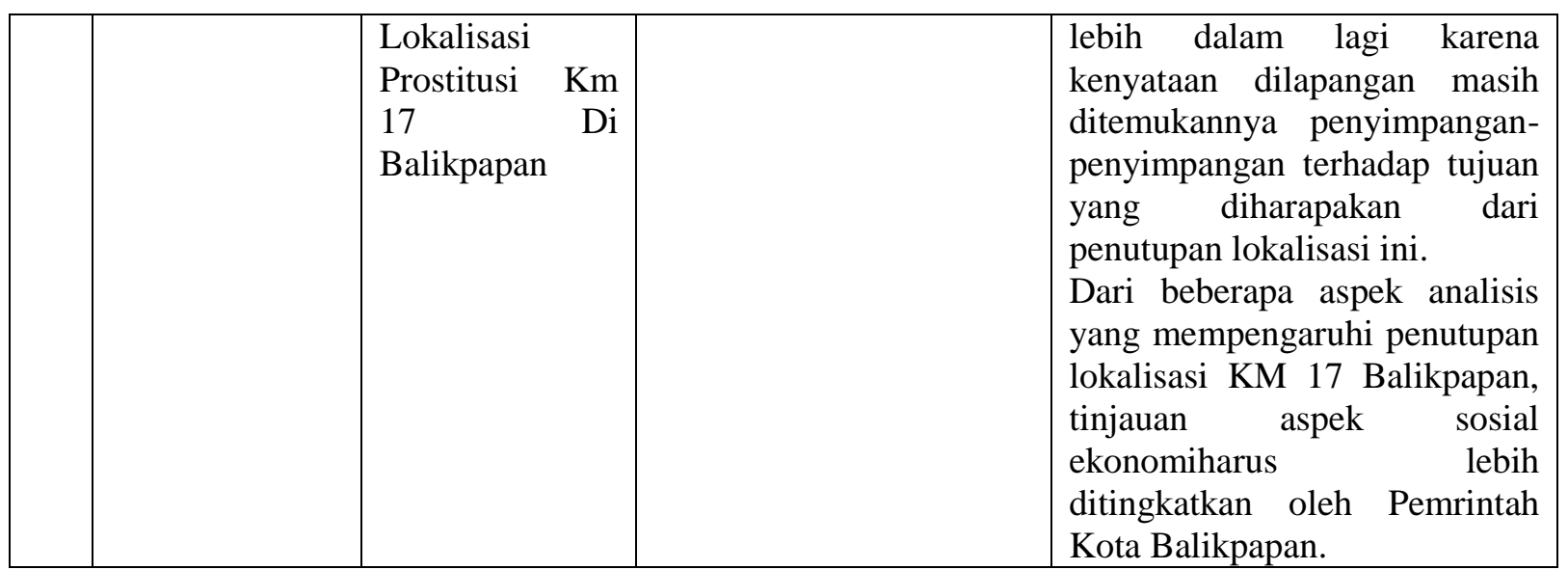

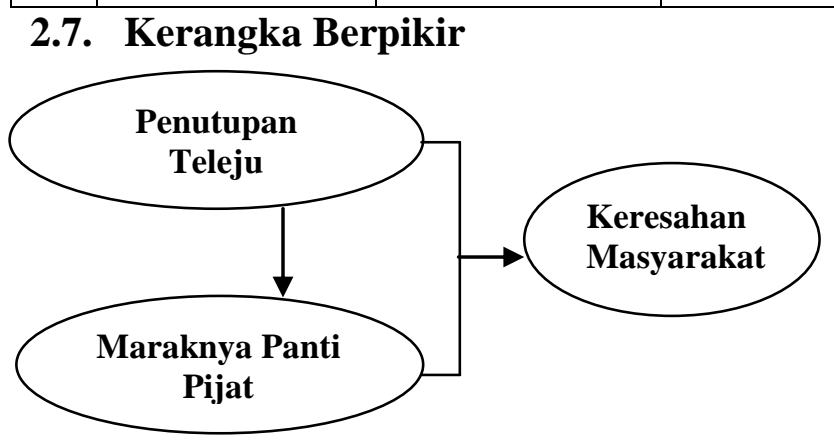

2. Data kuatitatif yaitu data yang dapat dihitung misalnya jumlah karyawan, pasien, dan lainnya.

4.2.2. Sumber Data

Sumber data yang akan menjadi bahan analisis dalam penelitian yaitu:

1. Data primer yaitu data yang diperoleh secara langsung dari tanggapan responden terhadap pertanyan yang diajukan dalam kuesioner .

III. VARIABEL PENELITIAN

Adapun variabel yang digunakan dalam penelitian ini:

1. Variabel Dependen,

$(Y)=$ Maraknya Panti Pijat

2. Variabel Independen,
$\left(\mathrm{X}_{1}\right)=$ Penutupan Teleju
$\left(\mathrm{X}_{2}\right)=$ Keresahan Masyarakat

\section{METEDOLOGI PENELITIAN}

\subsection{Lokasi Penelitian}

Lokasi Penelitian ini pada Panti Pijat yang tersebar di bebarapa Kecamatan di Kota Pekanbaru.

\subsection{Jenis dan Sumber Data,}

\subsubsection{Jenis Data}

Jenis data yang dikumpulkan, dibedakan menjadi dua kategori yaitu:

1. Data kualitatif yaitu data yang diperoleh dengan baik secara lisan maupun secara tertulis khususnya mengenai sejarah Kota pekanbaru dandata lainnya yang dapat menunjang pembahasan.

\subsection{Populasi dan Sampel \\ 4.3.1.Populasi,}

Sebagai populasi yang diambil pada penelitian ini adalah seluruh Panti Pijat yang berada di Kota Pekanbaru sebanyak 147 Tempat Panti Pijat Resmi maupun tidak resmi di Kota Pekanbaru

\subsubsection{Sampel,}

Teknik pengambilan sampelyang digunakan dalam penelitian menggunakan Random Sampling, dimana yang menjadi sampel adalah Pemilik dan masyarakat sekitar Panti Pijat yang tersebar di Kota Pekanbaru

\subsection{Analisis Data}

Dalam penelitian ini data yang didapat dari wawancara dan Observasi dilakukan analisis secara Kualitatif yang sangat mendalam tentang maraknya Panti 
Pijat dan Keresahan Pada masyarakat Kota Pekanbaru terutama di 8 Kecamatan yang beridiri panti Pijat.

\section{HASIL PENELITIAN}

\subsection{Sejarah Kawasan Teleju}

Kawasan Lokalisasi Teleju adalah

Kawasan Prostitusi Terbesar di Kota Pekanbaru Berada di RW 15 dan 16 Kelurahan Rejosari Kecamatan Tenayan Raya, Kawasan yang sengaja dibentuk menjadi tempat Prostitusi seperti Dolly di Surabaya, Sarkem di Yogyakarta dan Kalijodo di Jakarta, Kawasan yang menjadi ladang Perekonomian lebih dari 664 Pekerja Seks Komersial, 60 Germo, dan 200 Orang Kepala Keluarga di sana, Tidak hanya Warga asli Teleju yang menggantungkan hidup dari kawasan Prostitusi ini, tapi juga Tukang Ojek serta becak yang senantiasa selalu setia mengantarkan Pelanggan yang mau ke Lokalisasi Teleju, Tukang Ojek disana biasanya "Mangkal" dekat Mall Pekanbaru sekarang, Rute awal untuk mengantarkan Pelanggan setia ke Lokalisasi Teleju.

Pekerja Seks Komersial (PSK) di Lokalisasi Teleju berasal dari Pulau Jawa, dari Provinsi Jawa Barat, Mayotitas Berasal dari Indramayu, Lembang, Cirebon dan Tasikmalaya. Mereka datang ke Lokalisasi Teleju bermacam, macam, ada yang memang berniat menjadi "Pelacur" karena untuk mencari Uang dengan jalan yang cepat, Tingkat Pendidikan yang rendah, Ada yang juga karena ditawari bekerja di Malaysia, dan Batam, dan akhirnya dijual di Lokalisasi Teleju, Mereka mayotitas ditipu oleh Pencari Pekerja Seks Komersial yang memanfaatkan wanita-wanita muda di beberapa wilayah yang disebutkan diatas.

\subsection{Munculnya Panti Pijat di Pekanbaru}

Kawasan Lokalisasi Teleju resmi bersih dengan tanah pada tahun 2009, dan sekarang dibawah Pemerintahan Bapak Firdaus walikota Pekanbaru dibangunlah Rusunawa, Para Pekerja Seks di Kawasan Lokalisasi Teleju pindah dengan bermacam-macam aktifitas, ada yang pulang ke kampung halaman masingmasing, ada yang mendirikan praktek panti pijat yang akhirnya menjadi ladang baru prostitusi terselubung berkedok urut tradisonal, ada yang membuka salon, dan ada yang akhirnya membentuk komunitas baru bernama Jondul dan Lokalisasi Maredan.

\subsection{Kawasan Panti Pijat Jondul}

Praktik prostitusi di Perumahan Jondul lama, Jalan Kuantan, Kota Pekanbaru nyaris tak tersentuh. Kini, praktik kos-kosan yang berkedok usaha panti pijit tersebut berkembang menjadi lokalisasi protitusi. ratusan wanita berpakaian minim tampak berdiri di depan rumah. Sesekali, wanita yang didatangkan dari Jawa tersebut, membujuk para laki-laki hidung belang yang keluar masuk menggunakan sepeda motor.

Biaya pengobatan rawat inap di Rumah Sakit Awal Bros walaupun agak sedikit mahal dibandingkan dengan Rumah Sakit lain di Pekanbaru, tetapi masih terjangkau dan bekerja sama dengan Asuransi Pemerintah yaitu BPJS dan Asuransi yang berkelas Internasional

Sedangkan Rumah Sakit Putra Spesialis, Lebih mahal dan tetapi pasien dapat memilih alternatif kamar mulai dari yang paling mahal sampai yang murah (sal) dan setiap tagihan biaya rawat inap terperinci, mulai visite Dokter, biaya visite Nurses, Biaya alat Medis dan biaya obat-obatan dan biaya-biaya lain-lain.

\subsection{Kawasan Panti Pijat Maredan}

Melihat dari dekat lokalisasi di Maredan yang terdapat di perbatasan tiga kabupaten dan kota yakni Kota Pekanbaru, Kabupaten Pelawan, dan Siak, tepatnya JalanLintas Pekanbaru-Siak, lokalisasi tersebut memang berjarak beberapa ratus meter dari jalan yang telah di Semenisasi oleh PemerintahProvinsi (Pemprov) Riau pada 2013 lalu. Tempatnya juga dikelilingi perkebunan kelapa sawit. informasi yang didapat bahwa, lokalisasi tersebut masuk dalam wilayah Kota Pekanbaru. Saat kami sampai di lokalisasi tersebut, ternyata untuk masuk harus membayar uang 'ampang- 
ampang'. Hampir sama sepeeti di Lokalisasi Teleju dahulu kala Petugas pos meminta sebesar Rp10.000 Per Mobil yang masuk Di dalam lokalisasi itu, terlihat rumahrumah tempat tinggal sekaligus tempat usaha mereka, berderet-deret seperti di komplek perumahan. Sama seperti di Teleju yang telah digusur Pemko Pekanbaru tahun 2009 lalu.

Selain itu, terlihat pula banyak pedagang keliling yang menjajakan dagangannya. Mungkin karena hamper terisolir, dagangan mereka cukup diminati para penghuni lokalisasi. Barang yang dijual, selain kebutuhan harian, tentu saja juga ada alat kontra sepsi seperti kondom. Sebulan sekali, sales kondom juga menyambangi tempat ini menawarkan barang.

\subsection{Implikasi Terhadap Keresahaan Masyarakat}

Kehadiran Panti Pijat bisa membuat orang yang tidak berniat bisa terpengaruhi , soalnya ada dimana-mana kehadiran Panti Pijat yang tersebar di Kota Pekanbaru, Lokalisasi diciptakan untuk Melokalkan para Pekerja Seks Komersial ( PSK) tempat jauh dari keramaian, butuh dana besar dan segar untuk pergi kesana, karena masuk kesana harus menyema Ojek dan harus melewati 3 ( Tiga ) Pintu masuk yang dikenal dengan "Ampang-Ampang ", setiap ampang-ampang tersebut, konsumen harus membayar supaya bisa masuk dengan lancar dan aman, ketika Teleju di tutup Pemko Pekanbaru, para PSK lari ke tengah masyarakat dengan membangun usaha berkedok Panti Pijat, jadi masyakarat yang lewat bisa tertarik mencoba merasakan bagaimana nuansa yang tersaji di Panti Pijat tersebut.

\section{PENUTUP}

\subsection{Kesimpulan}

Panti Pijat di Pekanbaru marak berkembang Pasca ditutupnya Lokasilasi Teleju pada tahun 2009, Hampir disetiap Kecamatan di Kota Pekanbaru muncul Panti Pijat ibarat jamur dimusim Hujan, Mayotitas yang membuka Panti Pijat berasal dari Jawa Barat seperti Indramayu dan Palembang Sumatra Selatan, Panti Pijat hadir di rumah-rumah dan Ruko-Ruko Kontrakan, Praktek Panti Pijat hanya sebagai kedok belaka, karena mayoritas dari Observasi dan Wawancara di lapangan Praktek disana adalah Layanan Plus-Plus seperti Praktek Prostitusi yang ada di Lokalisasi Teleju.

1. Kehadiran Panti Pijat mayoritas menenimbulkan Keresahan di Masyarakat, Kehadiran Panti Pijat menimbulkan masalah baru yaitu Kriminalitas, Perkelahian Pemuda, Kenakalan Remaja dan Bahkan Keributan di Rumah Tangga. Kehadiran Panti Pijat yang Mayoritas di tengah-tengah masyarakat itu lah penyebabnya terjadi masalah-masalah baru yang mumcul.

2. Bisnis Panti Pijat memang menjadi sektor yang sangat ekonomi dan menjadi lahan bisnis bangi banyak pihak untuk meraup keuntungan, baik pemilik tempat panti pijat,warga setempat dan pihak keamanan yang tidak resmi terlibat dalam praktek tersebut, bahkan disalah satu lokasi panti pijat di Jondul, dari bisnis tersebut mereka dapat memperoleh kendaraan dari bisnis panti pijat dan bahkan sampai menyekolahkan anaknya.

\subsection{Saran}

Pemerintah Kota Pekanbaru sebagai Operator Kebijakan, harus belajar dari kasus penutupan Lokaliasi Telejju, Niat Baik Pemerintah untuk membrantas kemaksitan di Kota Pekanbaru malah menimbulka masalah baru, bukan hilang tapi malah bertambah, dan akhirnya Kota Pekanbaru dijamuri tempat maksiat berkedok Panti Pijat

Untuk Kawasan Prostitusi seperti Meredan dan Jondul tidak harus dibubarkan, tapi tidak harus dibiarkan, Pemerintah Kota melakukan Pengawasan yang terpadu dan hanya membuka Tempat panti Panti Pijat di Jondul dan Meredan saja, di Luar tempat tersebut dilakakuan peneindakan dan bahkan ditutup. 
Jika memang Pemerintah Kota Pekanbaru menutup dan membersihkan tempat Lokalisasi yang masih ada, sebaiknya diberi solusi seperti Pekerjaan dan Bisnis UMKM, Kasus Pembubaran Teleju tidak ada Solusi dari Pemerintah Kota , hanya menutup dibuat Rusunawa, yang Pulang kampung silahkan dan dikasih ongkos.

1. Pemerintah Kota Pekanbaru sebagai Operator Kebijakan, harus belajar dari kasus penutupan Lokaliasi Telejju, Niat Baik Pemerintah untuk membrantas kemaksitan di Kota Pekanbaru malah menimbulka masalah baru, bukan hilang tapi malah bertambah, dan akhirnya Kota Pekanbaru dijamuri tempat maksiat berkedok Panti Pijat

2. Pemerintah harus memberikan Pinjaman Moda untuk usaha dalam bentuk pinjaman lunak, Skill seperti Pelatihan menjahit, Pelatihan pengembangan usaha supaya mereka bisa mempunyai modal dalam bekerja dan berusaha, sehingga mereka tidak akan kembali membuka praktek Prostitusi dalam bentuk lain seperti
Panti Pijat, Salon yang orientasinya diluar dari seharusnya.

\section{DAFTA PUSTAKA}

Alison J Murai, 2004, Pedagang Jalanan dan Pelacuran Jakarta, Sebuah Kajian Antropologi, Jakarta : LP3ES

Elisabet Pisani,2008, Kearifan Pelacur ( Kisah Gelap di Balik Bisnis Sex ddan Narkoba), Jakarta : Serambi Ilmu

Endang Sulistiningsih, 1999, Prostitution in Indonesia, Jakarta : SH Book.

Jones, Pip. 2003. Pengantar Teori-Teori Sosial, terj. Ahmad Feryani Saifuddin. Jakarta : Yayasan Obor Indonesia.

Purnomo, Tjahto dan Siregar, Ashadi. 1984. Dolly : Membedah Dunia Pelacuran Surabaya, Kasus Kompleks Pelacuran Dolly, cet III. Jakarta : Graffitipress

Reno Bachtiar, 2007, Bisnis Prostitusi Profesi yang Menguntungkan, Jakarta : Pinus Book

Reno Bachtiar, 2007, Bisnis Prostitusi Profesi yang Menguntungkan, Jakarta : Pinus Book. 